\title{
Potential Allelopathy of Pine Leaf (Pinus Spp.) As Bioherbicide On Pigweed (Portulaca Oleracea)
}

\author{
Lutfy Ditya Cahyanti ${ }^{1}$, Titin Sumarni ${ }^{2}$ Eko Widaryanto ${ }^{2}$ \\ ${ }^{1}$ (Plant Science, Post Graduate Brawijaya University, Indonesia) \\ 2 (Department of Agronomy, Brawijaya University, Indonesia)
}

\begin{abstract}
The aims of this experiment was to study the effect of pine leaf as allelophaty on growth of pigweed. The experiment was conducted at screen house Department of Biology Faculty of Mathematics and Science, Brawijaya University. The research arranged by Randomized Simple Blok Design, with three replication, consisted of eleven levels, i.e : $A_{0}$ : Control, $A_{1}$ : Extract of leaf Pinus merkusii 400 ppm, $A_{2}$ : Extract of leaf Pinus merkusii 800 ppm, $A_{3}$ : Extract of leaf Pinus merkusii 1.200 ppm, $A_{4}$ : Extract of leaf Pinus merkusii 1.600 ppm, $A_{5}$ : Extract of leaf Pinus merkusii 2.000 ppm, $A_{6}$ : Extract of leaf Pinus longaeva 400 ppm, $A_{7}$ : Extract of leaf Pinus longaeva 800 ppm, $A_{8}$ : Extract of leaf Pinus longaeva 1.200 ppm, $A_{9}$ : Extract of leaf Pinus longaeva $1.600 \mathrm{ppm}, A_{10}$ : Extract of leaf Pinus longaeva $2.000 \mathrm{ppm}$. The results showed significant reduction by extract of leaf Pinus merkusii and Pinus longaeva 2000 ppm in plant height, leaf number, leaf area and dry weight of pigweed on observation 63 DAP. Extract of leaf Pinus merkusii and Pinus longaeva 2000 ppm affected plant height of pigweed $48 \%$ and $49 \%$ and affected leaf area $49 \%$ and $67 \%$ compared to control. Extract of leaf Pinus merkusii and Pinus longaeva 2000 ppm reduced dry weight of pigweed $38 \%$ and $37 \%$ compared to control.
\end{abstract}

Keywords: Allelophaty, Bioherbicide, Pinus merkusii, Pinus longaeva and Portulaca oleracea

\section{INTRODUCTION}

Pigweed is the potential competitor for crops. Pigweed is highly difficult to be controlled due to it is considered efficient in using sources to survive and grow rapidly as well. Such pigweed is competitive because it could adapt to any condition. It could grow under diverse condition of soil in all levels of nutrients, types of soil, altitudes, and in all levels of soil $\mathrm{pH}$, as well as temperature of the environment.

Allelophaty is an alternative to control pigweed as bioherbicide. Allelophaty of higher crops can be used to reduce the pigweed growth or pests. Method in using allelophaty as pigweed controller is relatively and efficiently safe way because it is a natural product that can be decomposed easily. Moreover, this allelophaty can be kept longer under varied condition and easily applicable.

Pine is one of perennial plants, which is potential as bioherbicide because of the content of allelophaty. Some research found that there is no herbs grow around the pine trees, however, it is assumed that mulch of the pine leaf on the soil has released allelophaty. Pine has resin channel that produces a secondary metabolite, which having allelophaty characteristic. The allelophaty belongs to terpenoid compounds, monoterpen $\alpha$-pinene and $\beta$ pinene. Such compounds are toxic for both insects and plants. The pine leaf contains allelophaty compounds, which is potential as selective bioherbicide so that it can be exploited economically. In general, such compounds possibly meet the criteria as bioherbicide economically and can be applied technically. (Senjaya and Surakusumah, 2007).

\section{HEADINGS}

The experiment was arranged based on Randomized Simple Block Design, with three replications, $\mathrm{A}_{0}$ : Control (without extract of pine leaf), $\mathrm{A}_{1}$ : Extract of leaf Pinus merkusii $400 \mathrm{ppm}, \mathrm{A}_{2}$ : Extract of leaf Pinus merkusii 800 ppm, $\mathrm{A}_{3}$ : Extract of leaf Pinus merkusii $1.200 \mathrm{ppm}, \mathrm{A}_{4}$ : Extract of leaf Pinus merkusii $1.600 \mathrm{ppm}$, $\mathrm{A}_{5}$ : Extract of leaf Pinus merkusii $2.000 \mathrm{ppm}, \mathrm{A}_{6}$ : Extract of leaf Pinus longaeva $400 \mathrm{ppm}, \mathrm{A}_{7}$ : Extract of leaf Pinus longaeva $800 \mathrm{ppm}, \mathrm{A}_{8}$ : Extract of leaf Pinus longaeva $1.200 \mathrm{ppm}, \mathrm{A}_{9}$ : Extract of leaf Pinus longaeva $1.600 \mathrm{ppm}, \mathrm{A}_{10}$ : Extract of leaf Pinus longaeva $2.000 \mathrm{ppm}$. The materials include the seeds of pigweed, leaves of Pinus merkusii and Pinus longaeva. The instruments include analytic scales, Oven, Leaf Area Meter, camera. The materials are seeds of pigweeds, soil, polybags

Experiment:

a. Preparing the Medium

Medium of $2 \mathrm{~kg}$ soil were filled into polybags of $15 \mathrm{~cm}$ in diameter.

b. Planting the Seeds of Pigweed

The seeds spread and then spaced and finally 1 crop was remained in 7 DAP.

c. Application of the Allelophaty 
The extract was given by pouring $100 \mathrm{ml} /$ polybag into the planting medium at the age of $14,21,28,35,42$, 49 and 56 DAP (days after planting)

Observation

a. The Growth of Pigweed

The observation was conducted both destructively and non-destructively, by taking sample of the crop for each treatment of the pigweed. Observation was taken when the age of pigweed reached 21, 28, 35, 42, 49, 56 and 63 DAP.

Components of the observed growth by non-destructive way include:

1. Height of the pigweed

2. Numbers of leaf

Components of the observed growth by destructive way include:

1. Leaf area of the pigweed

2. Total dry weight of the pigweed

\section{Height of the Pigweed}

\section{INDENTATIONS AND EQUATIONS}

Result for the analysis of variance showed that treatment by the application of both extracts of leaf in different concentration have insignificant effect on height of the pigweed within 21 and 28 DAP, but have significant effect on height within 35, 42, 49, 56 and 63 DAP. The height has been increasing in each interval of observation for each treatment. Mean of height for each age is presented in Table 1.

Application of the leaf extract P. merkusii $2.000 \mathrm{ppm}$ could reduce the height at the age of 35 DAP, $53 \%$, in comparison with the control (no treatment), meanwhile the application of leaf extract P. longaeva 2.000 ppm could reduce the height $57 \%$ in comparison with the control. At the age of 42 DAP, treatment on P. merkusii under concentration of $2.000 \mathrm{ppm}$ could reduce the height $53 \%$, while for P. longaeva $2.000 \mathrm{ppm}$ could reduce the height $59 \%$ in comparison with the control.

Table 1 shows that at the age of 49 DAP, the height under control treatment has significant difference in comparison with treatment by extract of leaf P. merkusii $2.000 \mathrm{ppm}$, which reduced $43 \%$, while the extract of leaf P. longaeva $2.000 \mathrm{ppm}$ could reduce $46 \%$. At the age of $56 \mathrm{DAP}$, the height of pigweed under control treatment has significant difference in comparison with the treatment of P. merkusii $2.000 \mathrm{ppm}$ and P. longaeva $2.000 \mathrm{ppm}$, which could reduce $61 \%$ and $50 \%$, respectively. Whereas, the height of pigweed under control treatment at the age of 63 DAP has significant difference in comparison with the treatment of leaf extract P. merkusii $2.000 \mathrm{ppm}$ and P. longaeva $2.000 \mathrm{ppm}$, which could reduce $48 \%$ and $49 \%$.

Observation on height of the pigweed at the age of 56 DAP showed that the treatment of P. merkusii $1.200 \mathrm{ppm}$ has significant difference in comparison with the control treatment, but insignificant difference with the treatment of leaf extract P. merkusii 400,800 and $1.600 \mathrm{ppm}$. At the age of 63 DAP, the treatment of P. merkusii and P. longaeva under concentration of $1.200 \mathrm{ppm}$ showed significant difference in comparison with the control.

Table 1 shows that at the age of 35, 42, 49, 54 and 63 DAP, the treatment of leaf extract P. merkusii and P. longaeva $400 \mathrm{ppm}$ do not affect the height in comparison with the control. Result of the observation showed that the height at the age of 35 DAP to 63 DAP under treatment of leaf extract P. merkusii $400 \mathrm{ppm}$ has insignificant difference with the treatment of P. merkusii 800, 1.200 and $1.600 \mathrm{ppm}$, while the height under treatment of P. longaeva $400 \mathrm{ppm}$ has insignificant difference with P. longaeva 800, 1.200 and $1.600 \mathrm{ppm}$, respectively.

\section{Numbers of Leaf}

Result for the analysis of variance showed that treatment using both extracts of leaf with different concentration have insignificant effect on numbers of leaf at the age of 21, 28 and 35 DAP, but have significant effect at the age of 42, 49, 56 and 63 DAP. Numbers of leaf have increased for each interval of observation for each treatment. Mean for numbers of leaf at all ages is presented in Table 2.

At the age of 42 DAP, numbers of leaf under treatment of leaf extract P. merkusii $2.000 \mathrm{ppm}, \mathrm{P}$. longaeva $1.200,1.600$ and $2.000 \mathrm{ppm}$ had significant difference in comparison with the control. Table 2 shows that at the age of 49, 54, and 63 DAP, treatments using extract of leaf P. merkusii $1.200 \mathrm{ppm}, 1.600 \mathrm{ppm}$, and $2.000 \mathrm{ppm}$ could significantly reduce numbers of leaf in comparison with the control for about $30 \%, 37 \%$, and $48 \%$, respectively. Numbers of leaf for the control at the age of 49, 54 and 63 DAP have significant difference in comparison with treatment using P. longaeva $1.200,1.600$, and $2.000 \mathrm{ppm}$ that could reduce $30 \%, 36 \%$ and $56 \%$, respectively, and observation at the age of 49,54 and 63 DAP, numbers of leaf for the control have insignificant difference in comparison with numbers of leaf under the treatment of P. merkusii 400 and 800 ppm, as well as P. longaeva 400 and 800 ppm. 
Numbers of leaf at the age of 56 DAP under the treatment of P. merkusii and P. longaeva $1.200 \mathrm{ppm}$ have significant difference in comparison with the control, and at the age of $63 \mathrm{DAP}$, treatment using P. merkusii $1.200 \mathrm{ppm}$ could reduce numbers of leaf in comparison with the control. However, treatment using P. longaeva $800 \mathrm{ppm}$ has significant difference in comparison with the control.

\section{Leaf Area}

Result for the analysis of variance showed that treatment using both extracts with different concentration had significant effect on leaf area at the age of 28, 35, 42, 49, 56 and 63 DAP. Leaf area has increased in each interval of observation on each treatment. Mean of leaf area for diverse age is presented in Table 3.

Data for result of the observation at the age of 28,35 and 42 DAP, showed that leaf area under the treatment of P. merkusii dan P. longaeva $400 \mathrm{ppm}$ had insignificant difference with the control, but under P. merkusii $800,1.200,1.600$, and $2.000 \mathrm{ppm}$, as well as P. longaeva $1.200,1.600$ and $2.000 \mathrm{ppm}$ had significant difference in comparison with the control.

At the age of 49 DAP, for control treatment, leaf area had insignificant difference with the treatment of P. merkusii $400 \mathrm{ppm}$, but it showed significant difference under the treatment of P. merkusii 800, 1.200, 1.600, and $2.000 \mathrm{ppm}$. For the control, leaf area showed significant difference as using P. longaeva 400, 800, 1.200, 1.600 and $2.000 \mathrm{ppm}$.

In Table 3, observation at the age of $56 \mathrm{DAP}$, shows that leaf area under control treatment has insignificant difference as treatment using extracts of leaf P. merkusii $800 \mathrm{ppm}$ and P. longaeva $400 \mathrm{ppm}$. Data of observation showed that for control treatment, leaf area has significant difference with treatment using P. merkusii 400, 1.200, 1.600 and 2.000 ppm, as well as with treatment using P. longaeva 800, 1.200, 1.600 and $2.000 \mathrm{ppm}$. While for control treatment on observation in $63 \mathrm{DAP}$, leaf area has insignificant difference as using P. merkusii 400, 800, and $1.200 \mathrm{ppm}$, as well as when using P. longaeva 400, 800 and $1.200 \mathrm{ppm}$.

For control treatment at the age of $63 \mathrm{DAP}$, leaf area showed significant difference in comparison with treatment using P. merkusii 1.600 and $2.000 \mathrm{ppm}$, as well as when using P. longaeva 1.600 and $2.000 \mathrm{ppm}$, however, the application of P. merkusii and P. longaeva $1.600 \mathrm{ppm}$ each could reduce leaf area $43 \%$ and $52 \%$, respectively, in comparison with the control.

\section{Dry Weight}

Result for the analysis of variance showed that treatment using both extracts with diverse concentration has significant effect on dry weight of pigweed at the age of 35, 42, 49, 56 and 63 DAP. Dry weight of pigweed has increased in each interval of observation for each treatment. Mean for dry weight of pigweed at diverse age is presented in Table 4.

Table 4 shows that dry weight, in control treatment, has significant difference in comparison with using P. merkusii $2.000 \mathrm{ppm}$ and P. longaeva $2.000 \mathrm{ppm}$ at the age of 35, 42, dan $49 \mathrm{DAP}$, but has insignificant difference with P. merkusii 400, 800 and 1.200 ppm, and insignificant difference with P. longaeva 400 and 800 ppm.

Data of observation showed that at the age of 56 DAP, dry weight for the control has insignificant difference as treatment using P. merkusii 400, 800, 1.200, and P. longaeva 400, 800 and $1.200 \mathrm{ppm}$. Dry weight for the control has significant difference in comparison with treatment using P. merkusii 1.600 and $2.000 \mathrm{ppm}$ as well as P. longaeva 1.600 and $2.000 \mathrm{ppm}$.

Dry weight for control treatment, at the age of 63 DAP has insignificant difference with treatment using P. merkusii 400 and 800 ppm, as well as P. longaeva 400 and 800 ppm. Treatment using P. merkusii 1.200 ppm reduces dry weight $33 \%$, while P. longaeva 1.600 ppm reduces $36 \%$ in comparison with the control.

Based on data of observation, it showed that treatment using allelopathy of both leaf extracts with diverse types and concentration affected on the growth of pigweed. Parameter of the growth include height of pigweed, numbers of leaf, leaf area, and dry weight, which have reduced along with higher concentration of allelopathy extract of pine leaf. The growth of pigweed in control treatment, without applying leaf extract of pine, is well-growth in comparison with the treatment of allelophaty extract of pine leaf, due to such allelopathy affects the growth of pigweed through metabolism activity, which include cell division and extension, regulating the growth by disturbing the growth regulator, taking the nutrients, photosynthesis, respiratory, stomatal opening, protein synthesis, accumulating carbon and pigment synthesis, permeability of membrane, and changing the function of specific enzyme (Einhellig, 1995).

In general, the higher the concentration of both extracts, they could affect the growth of pigweed. However, under specific concentration, the allelopathy compounds could inhibit and reduce the yield in physiological process of the plant. Such inhibition occurs during the formation of nucleatic acid and ATP. The reduced ATP could reduce for almost the entire cell metabolism process, therefore synthesis of other substances, which are required by the plants, will reduce as well (Rice, 1984; Salisbury and Ross, 1992). 
Allelopathy of both extracts affect leaf area of pigweed. Leaf area affetcs the photosynthetic rate due to leaf is the main organ where photosynthesis occurs, therefore narrow leaf area will produce lower photosynthate. Photosynthesis is a life cycle of a plant, a biochemical process to produce the used energy, in which carbon dioxide and water will be turned into organic compounds that contain carbon and energy, which is intermediated by light.

Photosynthesis is one of carbon assimilation because during this process, carbon is released from $\mathrm{CO}_{2}$ and bound into sugar as energy saver molecule. Glucose is used to form other organic compounds as cellulose and usable as fuel. This process persists through cellular respiration. In respiration, sugar (glucose) and other compounds will react to oxygen to produce carbon dioxide, water, and chemical energy.

Plants capture light using chlorophyll pigment, which provide green color to the plants. Chlorophyll is in organelle, which so-called chloroplast where photosynthesis occurs, particularly in stroma part. Even all parts of the plants are green due to the chloroplast content, but most of the energy are produced in leaf, besides that allelopathy could reduce stomatal conductance and turgor stress in leaf, simultaneously. Stomata and chlorophyll are components of biology, which determine the initial inthesis of the organic compounds for physiological process during life cycle of plant, therefore, when disturbance occurs, it will affect both growth and development of the plant.

Effectiveness in using allelopathy of both extracts can be seen from dry weight of the pigweed, which is effective when dry weight is lower that connecting to higher concentration of allelopathy. Dry weight of pigweed is affected by allelopathy extracts of pine leaf. In general, allelopathy affects the plant growth, in which the process is initiated in plasm membrane as the structural damages, modify the membrane channel, or loss of ATP-ase enzyme function, therefore it will affec the absorption and concentration of ion and water, and then will affect the stomatal opening and photosynthetic process (Einhellig, 1995). The next inhibition occurs during the process of protein synthesis, pigment and other carbon compounds, as well as activity of some phytohormone. A part or the entire inhibition will disturb cell division and enlargement, which will inhibit the growth and development of the targeted plant.

It has been found out that pine has resin channel, which produces secondary metabolite that having allelopathy feature. The allelopathy in such resin belongs to terpenoid compounds, monoterpen $\alpha$-pinene and $\beta$ pinene. The pinene compounds affect the metabolism process of plants, which causes cell function disturbance. Mechanism of such pinene compounds occurs in organelle, which is so-called cytochrome, cytochrome P 450, and cooperate with cytochrome b5 that adjacent to cytochrome P 450. This cytochrome lies adjacent to luminal surface of cell wall and cytoplasm surface. The pinene compounds, which enter to cell will be oxidized and will affect cell metabolism (Marisa, 1990), therefore it will affect the growth of pigweed.

The first paragraph under each heading or subheading should be flush left, and subsequent paragraphs should have a five-space indentation. A colon is inserted before an equation is presented, but there is no punctuation following the equation. All equations are numbered and referred to in the text solely by a number enclosed in a round bracket (i.e., (3) reads as "equation 3"). Ensure that any miscellaneous numbering system you use in your paper cannot be confused with a reference [4] or an equation (3) designation. (10)

\section{FIGURES AND TABLES}

Table 1. Mean for Height of Pigweed after the Treatment of Two Extracts of Pine Leaf with Different Concentration

\begin{tabular}{|c|c|c|c|c|c|c|c|c|c|c|c|c|}
\hline \multirow{2}{*}{ Treatment } & \multicolumn{12}{|c|}{ Mean of height $(\mathrm{cm})$ at diverse age (DAP) } \\
\hline & \multirow{2}{*}{$\begin{array}{c}21 \\
6,3\end{array}$} & \multirow{2}{*}{$\begin{array}{r}28 \\
10,7\end{array}$} & \multirow{2}{*}{$\frac{35}{18,6}$} & & \multicolumn{2}{|c|}{42} & \multicolumn{2}{|c|}{49} & \multicolumn{2}{|c|}{56} & \multicolumn{2}{|c|}{63} \\
\hline Control & & & & $\mathrm{b}$ & 22,0 & $\mathrm{~d}$ & $3^{27,}$ & $\mathrm{c}$ & 34,3 & $\mathrm{c}$ & 40,2 & $\mathrm{c}$ \\
\hline P. merkusii & & & & & & & & & & & & \\
\hline $400 \mathrm{ppm}$ & 5,3 & 10,0 & 13,6 & $\mathrm{ab}$ & 16,9 & $\mathrm{~cd}$ & 23,3 & bc & 26,3 & $\mathrm{bc}$ & 34,0 & $\mathrm{bc}$ \\
\hline $800 \mathrm{ppm}$ & 5,5 & 8,7 & 10,5 & $\mathrm{a}$ & 13,1 & $a b c$ & 21,3 & $a b c$ & 25,8 & $\mathrm{bc}$ & 29,8 & $a b c$ \\
\hline $1.200 \mathrm{ppm}$ & 5,0 & 7,1 & 11,6 & $\mathrm{a}$ & 12,9 & $a b c$ & 19,8 & $a b c$ & 22,7 & $a b$ & 24,1 & $a b$ \\
\hline $1.600 \mathrm{ppm}$ & 5,8 & 7,6 & 9,6 & $\mathrm{a}$ & 12,8 & $a b c$ & 18,1 & $\mathrm{ab}$ & 23,6 & $a b$ & 23,2 & $a b$ \\
\hline $2.000 \mathrm{ppm}$ & 5,4 & 7,8 & 8,9 & $\mathrm{a}$ & 10,4 & $\mathrm{ab}$ & 15,8 & $\mathrm{ab}$ & 13,7 & $\mathrm{a}$ & 21,1 & $\mathrm{a}$ \\
\hline P. longaeva & & & & & & & & & & & & \\
\hline $400 \mathrm{ppm}$ & 5,0 & 9,2 & 13,7 & $a b$ & 15,1 & $\mathrm{bc}$ & 22,1 & $a b c$ & 23,3 & $a b$ & 34,5 & $\mathrm{bc}$ \\
\hline $800 \mathrm{ppm}$ & 5,7 & 9,0 & 10,6 & $\mathrm{a}$ & 14,2 & $a b c$ & 19,6 & $a b$ & 22,4 & $a b$ & 30,1 & $a b c$ \\
\hline $1.200 \mathrm{ppm}$ & 5,0 & 9,4 & 11,0 & $\mathrm{a}$ & 12,6 & $a b c$ & 18,0 & $\mathrm{ab}$ & 19,3 & $a b$ & 29,4 & $a b c$ \\
\hline $1.600 \mathrm{ppm}$ & 4,6 & 8,2 & 8,8 & $\mathrm{a}$ & 11,7 & $a b c$ & 17,3 & $\mathrm{ab}$ & 21,7 & $a b$ & 22,7 & $a b$ \\
\hline $2.000 \mathrm{ppm}$ & 4,4 & 6,2 & 8,1 & $\mathrm{a}$ & 9,1 & $\mathrm{a}$ & 15,4 & $\mathrm{a}$ & 17,3 & $a b$ & 20,9 & $\mathrm{a}$ \\
\hline
\end{tabular}

Notes:

Numbers, which are accompanied by the same letter in the same column show insignificant difference based on Duncan test 5\%; DAP = days after planting; is = insignificant 
Table 2. Mean for Numbers of Leaf after the Treatment of Two Extracts of Pine Leaf with Different Concentration

\begin{tabular}{|c|c|c|c|c|c|c|c|c|c|c|c|}
\hline \multirow{4}{*}{$\begin{array}{l}\text { Treatment } \\
\text { Control } \\
\text { P. merkusii }\end{array}$} & \multicolumn{11}{|c|}{ Mean for numbers of leaf (blade) at diverse age (DAP) } \\
\hline & \multirow{2}{*}{$\frac{21}{5,3}$} & \multirow{2}{*}{$\frac{28}{11,7}$} & \multirow{2}{*}{$\frac{35}{18,0}$} & \multicolumn{2}{|c|}{42} & \multicolumn{2}{|c|}{49} & \multicolumn{2}{|c|}{56} & \multicolumn{2}{|c|}{63} \\
\hline & & & & 24,7 & $\mathrm{~d}$ & 34,0 & $\mathrm{c}$ & 42,3 & $\mathrm{c}$ & 50,0 & $\mathrm{c}$ \\
\hline & & & & & & & & & & & \\
\hline $400 \mathrm{ppm}$ & 4,3 & 8,3 & 11,0 & 21,3 & $\mathrm{~cd}$ & 28,0 & $\mathrm{bc}$ & 37,7 & bc & 43,3 & $\mathrm{bc}$ \\
\hline $800 \mathrm{ppm}$ & 4,3 & 8,3 & 10,0 & 19,3 & bcd & 27,7 & $a b c$ & 31,0 & $a b c$ & 36,0 & $a b c$ \\
\hline $1.200 \mathrm{ppm}$ & 4,3 & 6,3 & 9,7 & 17,3 & abcd & 22,0 & $\mathrm{ab}$ & 27,7 & $\mathrm{ab}$ & 33,3 & $a b$ \\
\hline $1.600 \mathrm{ppm}$ & 4,3 & 7,0 & 9,0 & 15,7 & abcd & 19,3 & $\mathrm{ab}$ & 26,7 & $\mathrm{ab}$ & 26,7 & $\mathrm{a}$ \\
\hline $2.000 \mathrm{ppm}$ & 4,3 & 6,7 & 9,3 & 13,0 & $\mathrm{ab}$ & 18,7 & a & 21,3 & $\mathrm{a}$ & 26,3 & $\mathrm{a}$ \\
\hline \multicolumn{12}{|l|}{ P. longaeva } \\
\hline $400 \mathrm{ppm}$ & 4,7 & 9,0 & 12,7 & 20,7 & $\mathrm{~cd}$ & 28,3 & $\mathrm{bc}$ & 33,0 & $a b c$ & 39,3 & $a b c$ \\
\hline $800 \mathrm{ppm}$ & 4,7 & 8,0 & 11,0 & 18,0 & abcd & 24,3 & $\mathrm{ab}$ & 30,0 & $a b c$ & 33,0 & $a b$ \\
\hline $1.200 \mathrm{ppm}$ & 4,0 & 7,0 & 9,7 & 17,3 & $a b c$ & 22,3 & $\mathrm{ab}$ & 28,3 & $\mathrm{ab}$ & 30,0 & $a b$ \\
\hline $1.600 \mathrm{ppm}$ & 4,0 & 6,3 & 9,3 & 16,0 & $a b c$ & 21,3 & $\mathrm{ab}$ & 27,7 & $\mathrm{ab}$ & 31,0 & $a b$ \\
\hline $2.000 \mathrm{ppm}$ & 4,0 & 5,3 & 7,7 & 11,0 & $\mathrm{a}$ & 19,0 & $\mathrm{a}$ & 22,7 & $\mathrm{a}$ & 25,7 & $\mathrm{a}$ \\
\hline
\end{tabular}

Notes:

Numbers, which are accompanied by the same letter in the same column show insignificant difference based on Duncan test $5 \%$; DAP = days after planting; = insignificant

Table 3. Mean for Leaf Area after the Treatment of Two Extracts of Pine Leaf with Different Concentration

\begin{tabular}{|c|c|c|c|c|c|c|c|c|c|c|c|c|}
\hline \multirow{3}{*}{$\begin{array}{c}\text { Treatment } \\
\text { Control }\end{array}$} & \multicolumn{12}{|c|}{ Mean of leaf area $\left(\mathrm{cm}^{2}\right)$ at diverse age (DAP) } \\
\hline & \multicolumn{2}{|c|}{28} & \multicolumn{2}{|c|}{35} & \multicolumn{2}{|c|}{42} & \multicolumn{2}{|c|}{49} & \multicolumn{2}{|c|}{56} & \multicolumn{2}{|l|}{63} \\
\hline & 5,4 & $\mathrm{c}$ & 6,9 & $\mathrm{c}$ & 9,3 & $\mathrm{c}$ & 14,8 & $\mathrm{c}$ & 18,0 & $\mathrm{c}$ & 21,2 & $\mathrm{~d}$ \\
\hline \multicolumn{13}{|l|}{ P. merkusii } \\
\hline 400 ppm & 4,0 & $a b c$ & 5,7 & $\mathrm{bc}$ & 7,2 & $a b c$ & 11,3 & bc & 13,1 & $\mathrm{~b}$ & 18,0 & bcd \\
\hline 800 ppm & 3,6 & $\mathrm{ab}$ & 4,9 & $a b$ & 6,8 & $\mathrm{ab}$ & 9,7 & $\mathrm{ab}$ & 12,0 & $\mathrm{abc}$ & 17,3 & bcd \\
\hline $1.200 \mathrm{ppm}$ & 3,5 & $\mathrm{ab}$ & 4,7 & $a b$ & 6,2 & $\mathrm{ab}$ & 9,1 & $\mathrm{ab}$ & 9,9 & $\mathrm{ab}$ & 14,6 & abcd \\
\hline $1.600 \mathrm{ppm}$ & 2,9 & a & 4,5 & $\mathrm{ab}$ & 6,1 & $\mathrm{ab}$ & 8,6 & $\mathrm{ab}$ & 8,6 & $\mathrm{ab}$ & 12,2 & $a b c$ \\
\hline $2.000 \mathrm{ppm}$ & 3,3 & $\mathrm{ab}$ & 3,6 & $\mathrm{a}$ & 4,9 & a & 7,9 & $\mathrm{ab}$ & 7,6 & $\mathrm{ab}$ & 10,9 & $\mathrm{ab}$ \\
\hline \multicolumn{13}{|l|}{ P. longaeva } \\
\hline 400 ppm & 4,0 & $a b c$ & 5,6 & $\mathrm{bc}$ & 7,3 & bc & 9,1 & $\mathrm{ab}$ & 13,8 & $\mathrm{bc}$ & 19,8 & $\mathrm{~cd}$ \\
\hline 800 ppm & 4,7 & $\mathrm{bc}$ & 4,6 & $\mathrm{ab}$ & 6,3 & $\mathrm{ab}$ & 9,0 & $\mathrm{ab}$ & 11,1 & $\mathrm{ab}$ & 15,1 & abcd \\
\hline $1.200 \mathrm{ppm}$ & 3,0 & a & 4,3 & $\mathrm{ab}$ & 6,1 & $\mathrm{ab}$ & 8,4 & $\mathrm{ab}$ & 10,8 & $\mathrm{ab}$ & 12,6 & abcd \\
\hline $1.600 \mathrm{ppm}$ & 2,9 & $\mathrm{a}$ & 4,0 & $\mathrm{ab}$ & 6,0 & $\mathrm{ab}$ & 6,8 & $\mathrm{ab}$ & 7,3 & $\mathrm{ab}$ & 10,2 & $\mathrm{ab}$ \\
\hline $2.000 \mathrm{ppm}$ & 2,8 & $\mathrm{a}$ & 3,7 & $\mathrm{a}$ & 4,9 & $\mathrm{a}$ & 5,5 & $\mathrm{a}$ & 5,9 & $\mathrm{a}$ & 7,1 & $\mathrm{a}$ \\
\hline
\end{tabular}

Numbers, which are accompanied by the same letter in the same column show insignificant difference based on Duncan test 5\%; DAP = days after planting; is = insignificant

Table 4. Mean for Dry Weight after the Treatment of Two Extracts of Pine Leaf with Different Concentration

\begin{tabular}{|c|c|c|c|c|c|c|c|c|c|c|}
\hline \multirow{3}{*}{$\begin{array}{c}\text { Treatment } \\
\text { Control }\end{array}$} & \multicolumn{10}{|c|}{ Mean of dry weight (g) at diverse age (DAP) } \\
\hline & \multirow{2}{*}{$\frac{35}{0,076}$} & \multicolumn{2}{|r|}{42} & & \multicolumn{2}{|c|}{49} & \multicolumn{2}{|c|}{56} & \multicolumn{2}{|c|}{63} \\
\hline & & $\mathrm{b}$ & 0,126 & $\mathrm{c}$ & 0,280 & $\mathrm{~d}$ & 0,350 & $\mathrm{c}$ & 0,380 & $\mathrm{~d}$ \\
\hline \multicolumn{11}{|l|}{ P. merkusii } \\
\hline $400 \mathrm{ppm}$ & 0,076 & $\mathrm{~b}$ & 0,100 & $\mathrm{bc}$ & 0,220 & $\begin{array}{l}\mathrm{bc} \\
\mathrm{d}\end{array}$ & 0,326 & $\mathrm{bc}$ & 0,330 & $\mathrm{~cd}$ \\
\hline $800 \mathrm{ppm}$ & 0,070 & b & 0,090 & $\begin{array}{l}a b \\
c\end{array}$ & 0,223 & $\begin{array}{l}\mathrm{bc} \\
\mathrm{d}\end{array}$ & 0,312 & $\mathrm{bc}$ & 0,313 & abcd \\
\hline $1.200 \mathrm{ppm}$ & 0,050 & $a b$ & 0,060 & $a b$ & 0,217 & $\begin{array}{l}\mathrm{bc} \\
\mathrm{d}\end{array}$ & 0,287 & $\begin{array}{l}\mathrm{ab} \\
\mathrm{c}\end{array}$ & 0,293 & $a b c$ \\
\hline $1.600 \mathrm{ppm}$ & 0,046 & $\mathrm{ab}$ & 0,056 & $\mathrm{ab}$ & 0,170 & $\mathrm{ab}$ & 0,257 & $\mathrm{ab}$ & 0,260 & $a b c$ \\
\hline
\end{tabular}




\begin{tabular}{|c|c|c|c|c|c|c|c|c|c|c|}
\hline $2.000 \mathrm{ppm}$ & 0,020 & $\mathrm{a}$ & 0,046 & a & 0,147 & a & 0,223 & $\mathrm{a}$ & 0,237 & $\mathrm{a}$ \\
\hline \multicolumn{11}{|l|}{ P. longaeva } \\
\hline $400 \mathrm{ppm}$ & 0,046 & $\mathrm{ab}$ & 0,083 & $\begin{array}{l}\mathrm{ab} \\
\mathrm{c}\end{array}$ & 0,250 & $\mathrm{~cd}$ & 0,317 & $\mathrm{bc}$ & 0,323 & bcd \\
\hline $800 \mathrm{ppm}$ & 0,063 & $\mathrm{~b}$ & 0,093 & $\begin{array}{l}\mathrm{ab} \\
\mathrm{c}\end{array}$ & 0,237 & $\begin{array}{l}\mathrm{bc} \\
\mathrm{d}\end{array}$ & 0,310 & $\mathrm{bc}$ & 0,313 & abcd \\
\hline $1.200 \mathrm{ppm}$ & 0,066 & $\mathrm{~b}$ & 0,070 & $a b$ & 0,233 & $\begin{array}{l}\mathrm{bc} \\
\mathrm{d}\end{array}$ & 0,267 & $\begin{array}{l}\mathrm{ab} \\
\mathrm{c}\end{array}$ & 0,283 & $a b c$ \\
\hline $1.600 \mathrm{ppm}$ & 0,046 & $a b$ & 0,070 & $a b$ & 0,203 & $\begin{array}{l}\mathrm{ab} \\
\mathrm{c}\end{array}$ & 0,260 & $a b$ & 0,240 & $a b$ \\
\hline $2.000 \mathrm{ppm}$ & 0,013 & $\mathrm{a}$ & 0,043 & $\mathrm{a}$ & 0,177 & $\mathrm{ab}$ & 0,233 & $\mathrm{a}$ & 0,240 & $a b$ \\
\hline
\end{tabular}

Notes:

Numbers, which are accompanied by the same letter in the same column show insignificant difference based on Duncan test 5\%; DAP = days after planting; is = insignificant

\section{CONCLUSION}

The allelopathy extracts of leaf Pinus merkusii and Pinus longaeva have affected height of plant, numbers of leaf, leaf area, dry weight, and numbers of well-opened stomata and chlorophyll content of the pigweed. At the age of $63 \mathrm{DAP}$, the allelopathy extract of leaf P. merkusii $2000 \mathrm{ppm}$ and P. longaeva $2000 \mathrm{ppm}$, which reduced the height $48 \%$ and $49 \%$, respectively. The allelopathy extract of leaf P. merkusii $2000 \mathrm{ppm}$ could reduce leaf area for about $49 \%$, and P. longaeva $2000 \mathrm{ppm}$ could reduce leaf area for about $67 \%$ at the age of 63 DAP.

\section{REFERENCES}

[1] Einhellig, FA. Allelopathy: Current status and future goals. American Chemical Society. Washington D.C, 1995.

[2] Marisa, H. The Effect of Pine Leaf Extract (Pinus merkusii) on Vegetative Growth and Germination of Soybean (Glycine max (L.) Merr.). Thesis of Postgraduate of Biology. The Technology Institute of Bandung. Bandung, 1990.

[3] Rice E. Biological Control of Weeds and Plant Diseases: Advances in Applied Allelopathy. Univ Oklahoma Press, Norman, USA, 1995

[4] Salisbury, F. B. \& Ross, C. W. 1992. Plant Physiology. Wardsworth Publishing Company. California. p. 23

[5] Senjaya and Surakusumah. Potential of Pine Leaf Extract (Pinus merkusii) as Bioherbicide to Inhibit the Germination of Echinochloa colonum L. and Amaranthus viridis. Parrenial (4), 2007, 1-5. 